is being deposited at the bottom of the trench, allowing microbes to thrive in this secluded habitat.

A second team reports that life exists in an even more unlikely environment. While at the University of North Carolina at Chapel Hill, Mark Lever and his colleagues found hydrogen-loving microbes in the oceanic crust, deep beneath the seabed off the west coast of North America. An incubation experiment over several years showed that the organisms can derive energy from geochemical reactions between iron compounds and the sea water that permeates through cracks in the rocky crust.

Nature Geosci. http://dx.doi.org/ 10.1038/ngeo1773 (2013); Science 339, 1305-1308 (2013) For a longer story on this research, see go.nature.com/ppzjaz

\section{CHEMISTR}

\section{Protecting DNA in silica 'amber'}

High temperatures and harsh chemicals degrade DNA, but not if it is protected by a skin of silica.

Robert Grass and his colleagues from the Swiss Federal Institute of Technology in Zurich immobilized DNA on charged silica particles and grew a 10-nanometre silica layer on top. The encapsulated DNA was variously subjected to strong ultraviolet radiation, humid $120^{\circ} \mathrm{C}$ heat and attack by reactive chemicals. Each time, the molecule could be recovered by dissolving the silica with a weak acid. The DNA remained largely undamaged (much as fossilized DNA is protected in amber) and its sequence could be easily read. The researchers used a $195^{\circ} \mathrm{C}$ press to create plastic pills (pictured) containing the protected DNA, which

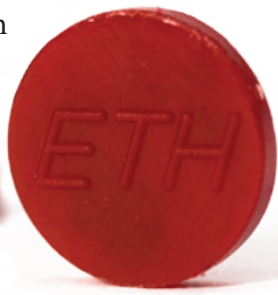

they suggest could be added to consumer goods as highsecurity barcodes.

Angew. Chem. http://dx.doi. org/10.1002/anie.201208135 (2013)

\section{BIOENGINEERING}

\section{Mobile worm microscope}

Smart phones may offer an affordable, portable way to diagnose intestinal worm infection, the most common infection in developing countries.

Isaac Bogoch at Toronto General Hospital in Canada and his group transformed an iPhone into a microscope by attaching an inexpensive lens to its camera. Almost 200 stool samples from children in Pemba Island, Tanzania, were mounted on slides and studied using the microscope. Experts identified more than $60 \%$ of worm-free slides, and nearly $70 \%$ of samples with eggs - of these, eggs from the large roundworm Ascaris lumbricoides had the highest rate of detection, at $81 \%$.

Although similar portable microscopes have been made before, most have stayed in the laboratory. The authors say that this is the first field-based clinical test of such devices for intestinal worms, and they predict that higher-resolution imaging will boost the accuracy of smart-phone diagnoses.

Am. J. Trop. Med. Hyg. http:// dx.doi.org/10.4269/ajtmh.120742 (2013)

\section{GEOLOGY}

\section{Quakes shake the gold out}

Earthquake after earthquake may build up economically important gold deposits by concentrating the precious metal along quartz-rich veins under the ground.

Dion Weatherley of the University of Queensland in Brisbane, Australia, and Richard Henley at the Australian National University in Canberra modelled jogs, or

COMMUNITY CHOICE

The most viewed papers in science

\title{
Mice poor models for inflammation
}

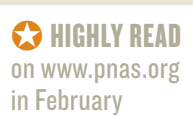

In a systematic evaluation of how well mice mimic human inflammatory responses, the popular disease model receives poor marks. A large multi-institute group co-led by Ronald Tompkins of Harvard Medical School in Boston, Massachusetts, studied genome-wide gene expression in blood samples from 35 healthy people and 411 people with burns, severe blunt trauma or sepsis. They also used public databases to gather human data for other acute inflammatory stresses. Shifts in gene expression as a result of stress were highly similar across the different groups of patients, but correlated poorly with those in a mouse model. Such disparities could lead to misleading results in studies of disease or in the development of therapies, the authors say. The quality of a disease model should be assessed not just for the appearance of disease but also for its biomolecular fidelity, they suggest.

Proc. Natl Acad. Sci. 110, 3507-3512 (2013)

cracks, that cross geological faults. Ground motions can drastically increase the volume of such cracks, causing liquids trapped in them to depressurize rapidly and precipitate out their minerals, say the researchers.

This process, known as flash vaporization, could happen repeatedly in geologically active and gold-rich areas, such as Indonesia and South Africa.

Nature Geosci. http://dx.doi. org/10.1038/ngeo1759 (2013) For a longer story on this research, see go.nature.com/6jwoxn

\section{ZOOLOGY}

\section{Frog feet share human hair origin}

The toe pads that allow tree frogs to cling to slippery surfaces share their origin with human hair.

Toe pads are complex structures that are held in shape by a rigid network of proteins. Wim Vandebergh and his colleagues at the University of Brussels found 200 gene sequences expressed in the toe pads of the tree frog Hyla cinerea (pictured), but nowhere else in its toe.

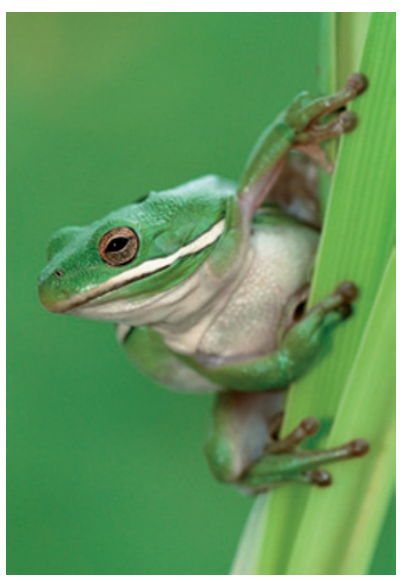

The authors identified five keratins that seem to be the main structural components of toe pads; the genes that encode these five proteins have the same evolutionary origin as those for the keratins found in mammalian hair follicles.

The authors say that these proteins must have arisen in an early tetrapod ancestor before diverging to become hair in mammals and toe pads in frogs.

Biol. Lett. 9, 20130051 (2013)

\section{DNATURE.COM}

For the latest research published by Naturevisit:

www.nature.com/latestresearch 